\title{
Economic damage to forage crops by native ungulates as perceived by farmers and ranchers in Montana
}

\author{
LYNN R. IRBY, WALTER E. ZWACK, JAMES B. JOHNSON, AND JOHN SALTIEL
}

\begin{abstract}
Authors are professor, Biology Department; research associate and professor, Agricultural Economics and Economics Department; and associate professor, Sociology Department, Montana State University, Bozeman, Mont. 59717.
\end{abstract}

\begin{abstract}
The perceived economic damage to forage crops in Montana attributed to native ungulates during 1992 was estimated using a mail survey of 2,200 randomly selected farms and ranches. The 1,120 respondents indicated that wild ungulates were present on $97 \%$ of the agricultural operations in Montana. White-tailed deer (Odocoileus virginianus [Zimmermann]) were the most widespread wild ungulate species and were most frequently cited as responsible for damage to forage crops by those respondents who reported damage. Damage to forage crops was most frequently reported in southwestern Montana and from agricultural operations with gross annual sales $>\$ 200,000$. The aggregate perceived economic damage to forage crops by wild ungulates in Montana during 1992 was $\$ 12.2$ million.
\end{abstract}

Key Words: forage damage, Montana, native ungulates

The system of public ownership of wildlife and private ownership of land that has developed in the United States has been successful in sustaining populations of native ungulates (Leopold 1933, Lenzini 1992). However, owners of private land sometimes incur economic losses from wild ungulates that live on their property (Matschke et al. 1984, Lacey et al. 1993, Wywialowski 1994). In Montana, arguments over the extent of damage have generated friction between agricultural producers and groups supporting wildlife. This friction could be reduced if more valid information on economic losses were available. In this paper, we have attempted to provide valid information on one class of economic damage, losses due to wild ungulate use of forage crops.

Landowners in Montana are expected to absorb some economic damage from wild animals. State Supreme Court rulings in cases such as State vs. Rathbone 1940 and State vs. Sackman 1968 have held that wildlife is an important asset to the state; use of the land by wildlife predates the current land ownership system; therefore, property owners in Montana should expect wildlife to live and feed on their property (Aderhold 1985). The state, by reducing a landowner's options, has taken on an obligation to protect landowners from unreasonable damage due to wildlife. When

This research was sponsored by the Montana Agricultural Experiment Station. The assistance provided by Lee Faulkner was greatly appreciated.

Manuscript accepted 1 Oct. 1995. unreasonable damage occurs, the Montana Department of Fish, Wildlife, and Parks (MDFWP) can offer the landowner an array of options to provide relief but will only issue a landowner a permit to kill depredating wild ungulates as a last resort (Aderhold 1985). The state does not provide direct monetary compensation for economic damage attributed to wildlife.

Determining "unreasonable" levels of economic damage is not an easy task because "reasonableness" is a value judgement based on perceptions of individuals and because measuring damage is difficult. Direct measurement of damage is very expensive, often provides inconclusive results, and usually has limited temporal and/or spatial applicability (Tebaldi 1979, Palmer et al. 1982, Grover 1985, Adkins 1991, Selting 1994).

Alternative approaches also have limitations. Public meetings or invited public comments on game damage can be easily biased by aggressive individuals or groups who may not be representative of the attitudes of the population (Vining and Ebreo 1991, Johnson et al. 1993). Assessing economic damage based on game damage complaints includes only the opinions of those landowners who complain (Adkins and Irby 1994). In-depth personal interviews provide detailed information but usually are limited to small samples which may not be representative of attitudes of the general population of landowners. Mail surveys to large segments of a population are relatively inexpensive and allow extensive coverage but may not be accurate indicators of attitudes (Dillman 1978). Question formulation can reflect conscious or unconscious biases of the groups sponsoring the survey. Respondents may or may not be representative of the population surveyed, and followup surveys on nonrespondents may be difficult or impossible if questions of confidentiality are involved.

An extensive survey was used in this study, despite the inherent limitations, because it provided a larger sample size and a better sample distribution than any other approach possible with the limited resources available. Problems associated with mail surveys were reduced because questions in this study were incorporated into an established annual survey, the Montana Farm and Ranch Survey (Saltiel and Faulkner 1993). This survey has been mailed to a random selection of farm and ranch operators since 1986 and has a reputation as a neutral source of information. The potential for exaggerated estimates of damage was reduced by including questions in a low profile, established survey in a year in which game damage was not a major issue in the state legisla- 
ture in a state where ranchers and farmers have low expectations of financial compensation for economic damage.

The only other recent attempts to survey landowner perceptions of game damage to agriculture in Montana have been limited to subpopulations of landowners in specific geographic areas within the state. Adkins (1991) found that numbers of damage complaints filed with MDFWP in southwestem Montana were positively correlated with hay prices and severity of weather conditions in early winter and negatively correlated with late spring precipitation and hunting opportunities on adjoining lands. Lacey et al. (1993) reported that the average annual economic loss attributed to wild ungulates by livestock producers in southwestern Montana was $\$ 6,467$ per operation. Forage loss in pastures and hayfields $(\$ 5,616)$ and damage to haystacks $(\$ 450)$ accounted for $94 \%$ of these estimated losses. Wywialowski (1994) included responses from Montana in a national survey of perceived damage, but results were reported by region rather than for individual states.

This survey was designed to develop baseline information on economic damage to agriculture in Montana by native ungulates as perceived by farmers and ranchers. Since $69 \%$ of the agricultural acreage in Montana is used to produce forage for livestock (MASS 1993), the survey emphasized relationships between wild ungulates and forage. The 3 objectives of this paper are:

1) to describe the distribution and extent of perceived economic damage to forage crops by wild ungulates in Montana,

2) to develop estimates of economic impacts of wild ungulates to hay stacks, hayfields, and rangeland in Montana based on perceived losses, and

3) to determine if perceived damage varies by geographic region and by operation size.

\section{Methods}

Data were obtained from the 1993 Montana Farm and Ranch Survey conducted in February and March of 1993. Questionnaires were mailed to a randomly selected sample of 2,200 of the 14,067 commercial farms and ranches $>40$ ha listed by the Montana Agricultural Statistics Service (MASS) (1993). Procedures for construction and administration followed recommendations by Dillman (1978). Letters reminding recipients to fill out the questionnaire and thanking those who had already done so were mailed 10 days after the questionnaires. Three of the 14 pages dealt with wildlife issues. Eleven pages dealt with economic conditions on individual operations, expectations for product prices, and farm and ranch management strategies. In order to maximize the probability of honest responses on questions related to personal financial status, the respondents were guaranteed anonymity. Potential bias in respondents was indirectly assessed through comparisons with responses in other years and with other data bases. Bias in questions was reduced by pretesting. Ranchers, farmers, extension agents, and MDFWP biologists completed and commented on preliminary versions of survey questions.

Recipients of the questionnaire were asked to indicate which species of wild ungulates were present on their lands, if they had experienced damage to haystacks, hayfields, and/or forage in pastures available for livestock use in 1992, and if damage in 1992 was below, near, or above average. For each type of damage, recipients were asked to identify which species ( 1 or more) were most responsible. Only 4 ungulate species, white-tailed deer, mule deer (Odocoileus hemionus [Rafinesque]), pronghorn antelope (Antilocapra americana [Ord.]), and elk (Cervus elaphus [L.]), were mentioned by respondents frequently enough for individual analyses.

Respondents that reported damage were asked to estimate the amount of loss during 1992 in tons for hayfields and haystacks and Animal Unit Months (AUM's) for forage in pastures. Reported damage was cross-checked with numbers of wild ungulates reported by season, operation size, and geographic location of the operation to eliminate infeasible estimates. No attempt was made to adjust losses of forage in pastures for dynamic plant growth processes (McNaughton 1983). Failure to adjust for this could have substantial impacts in some ecosystems, but in an extensive assessment of perceived forage losses over a large geographic area, a straight conversion of numbers of wild ungulates to AUM's based on approximate body size of the ungulate species (the most common manner by which respondents evidently estimated forage loss) provided the most reasonable approach available. The 1992 average market values for hay in Montana was $\$ 60$ per ton (USDA Agriculture Market Service 1993). Market value for grazing leases in the state in 1992 averaged $\$ 11.80$ per AUM (USDA Agricultural Statistics Service 1993). These averages were used to calculate the monetary value of loss estimates provided by respondents.

Perceived economic losses were calculated for haystack damage, forage consumed from hayfields, forage consumed from pastures, and an aggregate of damage in these categories for each operation. These values were used to calculate means and standard errors (SE) for the respondent sample. Respondent means and SE's were expanded to statewide estimates by multiplying them by 14,067 , the estimated total population of commercial farms and ranches $>40$ ha in Montana in 1992 (MASS 1993). Variation is reported as \pm 2 standard errors.

Differences in frequency of perceived economic damage by geographic region and by operation size were tested using chisquare tests of independence (SAS 1987). Montana was divided into 4 geographic regions (Fig. 1). Northwestern Montana had the highest percentage of forest cover, the lowest percentage of private land, and the smallest average operation size of the 4 regions. The northwestern region included approximately $17 \%$ of the area, $18 \%$ of agricultural operations, and $5 \%$ of the farmranch acreage in Montana (USDA Geographic Area Services

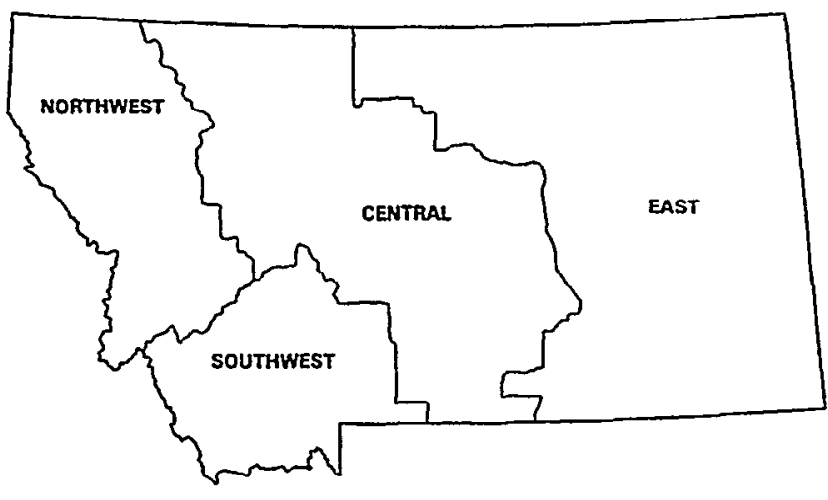

Fig. 1. Boundaries of geographic regions in Montana used to divide respondents into groups. 
1987). Southwestern Montana was characterized by forested mountain ranges separated by grasslands and included $12 \%$ of total acreage, $11 \%$ of farms and ranches, and $9 \%$ of farm and ranch acreage. Central Montana included some publicly owned mountainous lands along the eastern side of the Rocky Mountains but was predominantly privately owned prairie. This region had $30 \%$ of the total area of Montana, 35\% of agricultural operations, and $35 \%$ of the agricultural acreage in the state. Eastern Montana had the highest percentage of private agricultural land of the 4 geographic regions and was predominantly prairie. It included $41 \%$ of total area, $35 \%$ of farms and ranches, and $50 \%$ of the land devoted to farming and ranching in Montana.

Gross annual sales of agricultural products for individual operations was used as an index to operation size. The categories were $<\$ 50,000$ in sales, $\$ 50,000-200,000$ in sales, and $>\$ 200,000$ in sales.

Estimates of economic damage were also divided into 4 classes for statistical tests: 1 ) $<\$ 100$ (an amount that would likely be impossible to measure); 2) $\$ 100-500$ (an amount that would probably be measurable but not unreasonable); 3) $\$ 500-1,000$ (a cost to an operation that was borderline, i.e. could be considered for coverage in a compensation program or could fall under the "reasonable" damage rule); and 4) > \$1,000 (an amount that could represent "unreasonable" damage).

\section{Results}

\section{Characteristics of Respondents}

of the 2,200 questionnaires mailed, 292 were undeliverable because of death of an operator or sale of property or were returned by retired operators, and 1,120 produced usable replies. This was a $59 \%$ response rate $(1120 /[2,200-292])$ for people currently operating a farm or ranch and included almost $8 \%$ of the commercial farms and ranches listed by the MASS. The average gross sales of agricultural products in 1992 reported by respondents was $\$ 136,377$. Crop producers ( $\geq 70 \%$ of gross sales from crops) comprised $36 \%$ of the sample, livestock operations $(\geq 70 \%$ of gross sales from livestock) $43 \%$, and mixed operations $(\geq 30 \%$ of sales from both livestock and crops) $21 \%$. Crop operations averaged 680 ha. Livestock operations averaged 1,700 ha. Eleven percent of respondents were from northwestern Montana, 11\% from southwestern Montana, 39\% from central Montana, and 39\% from eastern Montana. The 1993 response rate was similar to those in 1991, 1992, and 1994 (Saltiel and Faulkner 1991, 1992, 1993, 1994).

\section{Distribution of Wildlife and Damage}

Ninety-seven percent of the 1,120 respondents reported wild ungulates on lands they controlled. Eighty-one percent of respondents reported white-tailed deer on their property, $76 \%$ mule deer, 59\% pronghorn antelope, and $21 \%$ elk. Mule and whitetailed deer were distributed throughout the state, but antelope were common only in the central and eastern regions and elk in the western regions.

Forty-nine percent of the survey respondents indicated they suffered economic losses to forage crops from wild ungulates. Consumption of forage in pastures was most frequently cited (44\%), followed by consumption of forage from hayfields (36\%) and haystack damage (30\%). Sixty-eight percent of respondents who reported loss of forage in pastures perceived losses in 1992 as average, $26 \%$ above average, and $5 \%$ below average. The patterns for those reporting losses to hayfields (67\% average, $27 \%$ above average, and $6 \%$ below average) and haystacks (55\% average, $30 \%$ above average, and $15 \%$ below average) were similar.

The frequencies at which species were reported as being responsible for damage varied among damage types (chi-square $=$ 106.10, $\mathrm{P}<0.01$ ). For respondents reporting damage, white-tailed deer were noted as most responsible for losses in haystacks and hayfields. White-tailed deer and mule deer were most frequently cited as responsible for forage loss in pastures (Table 1). Antelope were least frequently noted as responsible for haystack damage, and elk were noted least frequently as responsible for damage to hayfields and pastures.

\begin{tabular}{|c|c|c|c|}
\hline \multirow[t]{2}{*}{ Species } & \multicolumn{3}{|c|}{ Damage to } \\
\hline & $\begin{array}{c}\text { Haystacks } \\
(n=335)\end{array}$ & $\begin{array}{l}\text { Hayfields } \\
(n=400)\end{array}$ & $\begin{array}{l}\text { Pasture } \\
(n=524)\end{array}$ \\
\hline & \multicolumn{3}{|c|}{$\ldots(\%) \cdots \ldots$} \\
\hline White-tailed deer & 68 & 69 & 57 \\
\hline Mule deer & 57 & 56 & 56 \\
\hline Elk & 12 & 15 & 23 \\
\hline Pronghom antelope & 7 & 34 & 44 \\
\hline
\end{tabular}

Geographic regions differed in the frequency of reported damage to haystacks (chi-square $=49.07, \mathrm{P}<0.01$ ), hayfields (chisquare $=19.16, \mathrm{P}<0.01$ ), forage loss from pastures (chi-square $=$ $31.43, \mathrm{P}<0.01$ ), and for aggregated damage to forage crops (chisquare $=57.05, \mathrm{P}<0.01$ ). Southwestern Montana had the highest frequency of damage reports (Fig. 2) in all 4 categories.

Frequency of reported damage also varied with gross farm income (chi-square $=15.02,11.13,6.07$, and 8.41 for haystacks, hayfields, pastures, and aggregate damage, respectively; $\mathrm{P}<0.05$ ). Larger operations reported higher frequencies of damage in all damage categories (Fig 3).

\section{Economic Impacts}

Based on 1992 market values for hay and pasture forage, the average aggregate loss from wild ungulate use of forage crops in 1992 was $\$ 864$ ( $\pm \$ 143$ ) per respondent. The perceived losses on individual agricultural operations varied from none to $\$ 31,180$. Estimates for individual damage categories were $\$ 174( \pm \$ 35)$ for haystack damage, $\$ 344( \pm \$ 75)$ for growing hay consumed in fields, and $\$ 347$ ( $\pm \$ 81$ ) for forage consumed from pastures.

Expanding the average aggregate loss per operation to the population of 14,067 commercial farms and ranches produced a statewide estimate of damage to forage crops of $\$ 12.2$ million $( \pm \$ 2.0$ million). Statewide estimates of losses for specific types of damage were $\$ 2.4$ million ( $\pm \$ 0.5$ million) for haystack damage, $\$ 4.8$ million ( $\pm \$ 1.0$ million) for forage consumed from hayfields, and $\$ 4.9$ million ( $\pm \$ 1.1$ million) for forage consumed from pastures.

Estimated losses by respondents reporting damage (Table 2) did not vary significantly among loss categories by geographic 


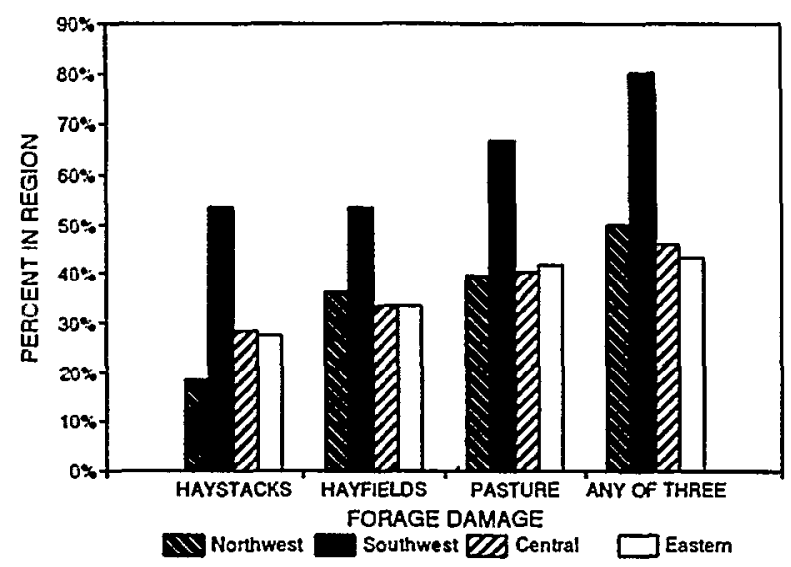

Fig. 2. Frequency of reported damage to haystacks, hayfields, forage in pastures, and one or more damage types by geographic region. Frequencies are based on $124,127,433$, and 434 respondents in the Northwest, Southwest, Central, and East regions, respectively.

region (chi-square $=2.7-14.4, \mathrm{P}=0.11-0.98$ ). Losses did vary significantly $(P<0.01)$ by farm sales categories (Table 3$)$ for haystack damage (chi-square $=36.4$ ), forage consumption from hay fields (chi-square $=16.9$ ), forage consumption from pastures (chi-square $=72.0$ ), and aggregate damage to forage crops (chisquare $=54.9$ ). Farms with the highest sales reported the highest frequency of damage $>\$ 1,000$ for all damage types.

\section{Discussion}

Although respondents in this survey reported slightly larger mean farm and ranch sizes than the average reported by MASS (1993), they were representative of the size, economic conditions, spatial distribution within the state, and agricultural practices of fulltime commercial operations within Montana (MASS 1993; Saltiel, unpubl.). Because this was the first statewide survey on the distribution of wild ungulates on agricultural lands in Montana, we could not contrast our results on animal distribution

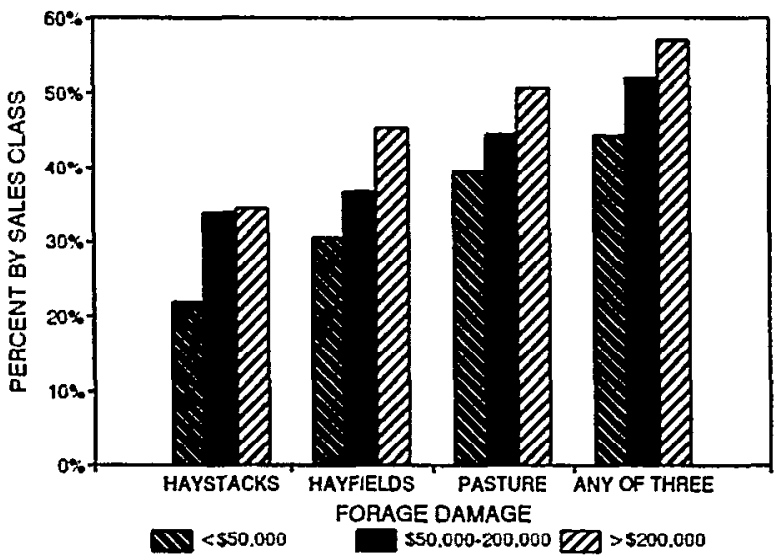

Fig. 3. Frequency of reported damage to haystacks, hayfields, forage in pastures, and one or more damage types by gross annual sales category. Frequencies are based on 325, 432, and 186 respondents in the $<\$ 50,000, \$ 50,000-\$ 200,000$, and $>\$ 200,000$ categories, respectively.
Table 2. Distribution of respondents reporting damage from wild ungulates among loss categories by geographic regions in Montana, 1992.

\begin{tabular}{|c|c|c|c|c|c|}
\hline \multirow[t]{2}{*}{$\begin{array}{l}\text { Damage } \\
\text { category }\end{array}$} & \multirow{2}{*}{$\begin{array}{l}\text { Number of responder } \\
\text { reporting damage }\end{array}$} & \multicolumn{4}{|c|}{ Loss category } \\
\hline & & $<\$ 100$ & $\$ 100-500$ & $\$ 500-1$ & 1,000 \\
\hline & & $\cdots$ & $\cdots-\cdots($ & (c) $)^{1}=$. & $\cdots$ \\
\hline \multicolumn{6}{|l|}{ Haystacks } \\
\hline Northwest & 19 & 26 & 47 & 16 & 10 \\
\hline Southwest & 67 & 18 & 39 & 22 & 21 \\
\hline Central & 116 & 16 & 37 & 24 & 23 \\
\hline East & 106 & 16 & 42 & 28 & 13 \\
\hline \multicolumn{6}{|l|}{ Hayfields } \\
\hline Northwest & 41 & 5 & 39 & 22 & 34 \\
\hline Southwest & 51 & 12 & 31 & 24 & 33 \\
\hline Central & 103 & 8 & 35 & 20 & 37 \\
\hline East & 106 & 7 & 35 & 24 & 34 \\
\hline \multicolumn{6}{|l|}{ Pasture } \\
\hline Northwest & 47 & 32 & 53 & 8 & 6 \\
\hline Southwest & 78 & 20 & 44 & 18 & 18 \\
\hline Central & 160 & 22 & 39 & 16 & 23 \\
\hline East & 156 & 22 & 49 & 10 & 18 \\
\hline \multicolumn{6}{|c|}{ Haystack, hayfield, and/or pasture } \\
\hline Northwest & 62 & 13 & 40 & 19 & 27 \\
\hline Southwest & 102 & 10 & 32 & 21 & 37 \\
\hline Central & 199 & 12 & 27 & 16 & 46 \\
\hline East & 188 & 11 & 32 & 20 & 37 \\
\hline
\end{tabular}

${ }^{1}$ Sums may not add to $100 \%$ due to rounding.

with other studies. However, the general distribution pattern obtained from respondents for deer, antelope, and elk was similar to that reported by MDFWP (Mussehl et al. 1986). The similarity between our sample of farmers and ranchers and statewide data bases suggests that the likelihood of sampling bias in this survey was low and that most of the private agricultural land in Montana not only supports livestock and crops but also supports native ungulates.

The extraordinarily high percentage (97\%) of respondents that reported native ungulates on their property would indicate response bias in some states, but this is unlikely in Montana. Wild ungulates are abundant; agricultural practices are generally extensive rather than intensive so suitable habitat is available throughout the state; and farmers and ranchers have traditionally tolerated wild animals on their lands. White-tailed and mule deer were the most frequently reported wild ungulates on farms and ranches. They were also most frequently noted as responsible for damage to forage crops.

There were undoubtedly biases in perceived losses reported in this survey. Respondents were asked to estimate forage loss from pastures in AUM's, and they apparently based their estimates on direct conversion of wild ungulate numbers to equivalent weights of cattle or sheep. This conversion did not take into account differences in food habits, habitat use, and physiology among domestic and wild ungulate species (Mackie 1981, Short 1981, Kitchen and O'Gara 1982, Nelson 1982, Nelson and Leege 1982, Peek and Dalke 1982, Peek 1984, Verme and Ullrey 1984, Wood et al. 1989); loss of forage to small mammals, insects, and decomposition (Batzli and Pitelka 1970, Clay et al. 1993, Quinn et al. 1993); or impacts of grazing on vegetation dynamics (Coughenour 1991, Frank and McNaughton 1992, Seagle and McNaughton 1992, Wallace and Macko 1993). Had adjustments for these factors been made, reported damage might have been lower, but there is no doubt that respondents were correct in assuming that some of the forage taken by wild ungulates could have been ingested by livestock. 
Table 3. Distribution of respondents reporting damage from wild ungulates among loss categories by annual farm sales categories during Montana, 1992.

\begin{tabular}{|c|c|c|c|c|c|}
\hline \multirow{2}{*}{\multicolumn{2}{|c|}{$\begin{array}{l}\text { Damage Number of responde } \\
\text { category reporting damage }\end{array}$}} & \multicolumn{4}{|c|}{ Loss category } \\
\hline & & $<\$ 100$ & $\$ 100-500$ & $\$ 500-1$ & 1,000 \\
\hline \multicolumn{6}{|l|}{ Haystacks } \\
\hline $\begin{array}{l}>\$ 50,000 \\
\$ 50,000-200,000 \\
>\$ 200,000\end{array}$ & $\begin{array}{r}68 \\
140 \\
61\end{array}$ & $\begin{array}{r}31 \\
15 \\
3\end{array}$ & $\begin{array}{l}44 \\
41 \\
28\end{array}$ & $\begin{array}{l}18 \\
27 \\
31\end{array}$ & $\begin{array}{r}7 \\
17 \\
38\end{array}$ \\
\hline $\begin{array}{l}\text { Hayfields } \\
<\$ 50,000 \\
\$ 50,000-200,000 \\
>\$ 200,000\end{array}$ & $\begin{array}{r}78 \\
128 \\
64\end{array}$ & $\begin{array}{l}9 \\
9 \\
3\end{array}$ & $\begin{array}{l}47 \\
33 \\
25\end{array}$ & $\begin{array}{l}24 \\
21 \\
23\end{array}$ & $\begin{array}{l}19 \\
38 \\
48\end{array}$ \\
\hline $\begin{array}{l}\text { Pastures } \\
<\$ 50,000 \\
\$ 50,000-200,000 \\
>\$ 200,000\end{array}$ & $\begin{array}{r}117 \\
182 \\
88\end{array}$ & $\begin{array}{r}39 \\
21 \\
2\end{array}$ & $\begin{array}{l}50 \\
44 \\
39\end{array}$ & $\begin{array}{r}4 \\
17 \\
22\end{array}$ & $\begin{array}{r}6 \\
18 \\
38\end{array}$ \\
\hline $\begin{array}{l}\text { Haystack, hayfield, an } \\
<\$ 50,000 \\
\$ 50,000-200,000 \\
>\$ 200,000\end{array}$ & $\begin{array}{l}2 d / \text { or past } \\
144 \\
224 \\
106\end{array}$ & $\begin{array}{r}\text { ure } \\
18 \\
10 \\
2\end{array}$ & $\begin{array}{l}43 \\
26 \\
19\end{array}$ & $\begin{array}{l}17 \\
20 \\
17\end{array}$ & $\begin{array}{l}22 \\
44 \\
62\end{array}$ \\
\hline
\end{tabular}

${ }^{1}$ Sums may not add to $100 \%$ duc to rounding.

Although the aggregate economic value of forage estimated to have been taken by wild ungulates on agricultural land in Montana, approximately $\$ 12$ million, is substantial, it is relatively small when compared to the $\$ 1$ billion value of livestock production in the state in 1992 (MASS 1993). The total value of all hay produced in Montana during 1992 was $\$ 321$ million (MASS 1993). The perceived loss of hay to wild ungulates, $\$ 7.2$ million, represented only $2 \%$ of the total value.

As would be anticipated, the perceived losses were not evenly distributed among agricultural producers in Montana. This uneven distribution raises 2 related questions. Which losses are reasonable or unreasonable, and what criteria should be should be employed to classify losses? In Idaho, indemnification is based on absolute criteria (Rimby et al. 1991). That is, losses above some dollar limit $(\$ 1,000$ in Idaho) are considered reasonable for indemnification and losses below this limit are not considered reasonable for indemnification. Such criteria require the verification of the absolute levels of loss by the administering agency.

In Montana, agriculture is dominated by extensive rather than intensive production, and gross sales in our sample were positively correlated with acreage. Large farms and ranches often support more wildlife, and more wild ungulates can potentially consume more forage. As anticipated, a greater percentage of the larger farms and ranches in Montana recorded perceived losses $>\$ 1,000$.

The high levels of damage reported in southwestern Montana in our survey and by Lacey et al. (1993) illustrate that damage complaint levels are tied not only to operation size but to topography and land ownership patterns. Southwestern Montana is characterized by wide valleys dominated by sage steppe vegetation separated by forested mountain ranges. The federal government owns much of the mountain land, and private cattle ranchers own most of the valley lands. Wild ungulates that summer on federal land frequently move to private lands at lower elevations in winter and use forage on private lands.

Fifty-one percent of respondents did not report any damage to forage crops. Of those respondents that did report damage to for- age crops, $61 \%$ indicated losses valued at $<\$ 1,000$. The small operations (22\% of those that reported damage) and medium to large operations ( $50 \%$ of those that reported damage) that reported losses valued at $>\$ 1,000$ would constitute the major compensation claim pool under the Idaho system. These farmers and ranchers perceived an aggregate mean damage to forage crops of $\$ 3,941$ per operation.

The results of this survey provide a conservative estimate of claims that might be expected under a compensation program based on perceived forage losses. Lacey et al. (1993) identified other economic losses (fencing material, labor, etc.) that ranchers could claim if a program were available, and personnel involved in compensation programs in Wyoming (Harju, pers. commun.) and Idaho (Thomas, pers. commun.) found that claims increased as ranchers and farmers became more aware of availability of game damage compensation funds.

Absolute criteria do not represent the only method of determining which perceived losses are reasonable or unreasonable. In some crop insurance and disaster relief programs (Goodwin and Smith 1995), a threshold level of loss in gross sales is specified before any indemnification occurs. For instance, if the loss in gross sales does not exceed $30 \%$ of a rolling average based on a prior specified period, there would be no indemnification of crop loss. If this approach were applied to wild ungulate damage, losses above $2 \%$ of gross sales (a value based on the state average of perceived damage to forage of $1-2 \%$ of total livestock sales) might be considered for indemnification. Farms and ranches with $\$ 50,000$ in gross sales would be indemnified for loss above $\$ 1,000$, and operations with gross sales of $\$ 200,000$ would only be indemnified for losses of more than $\$ 4,000$. Such a scheme would reduce the budget exposure for indemnification payments to the agency responsible for payments but would increase the administrative workload by requiring both verification of losses due to wild ungulates and the decline in gross sales relative to some benchmark formula.

This paper did not address economic and esthetic benefits farmers and ranchers might derive from wild ungulates on their lands. Many farmers and ranchers enjoy seeing and/or hunting wild animals on their lands. Others derive income directly from hunting leases or indirectly from premiums paid by wealthy immigrants to Montana for land with wildlife. Lacey et al.(1993) indicated that economic gains from hunting leases did not come close to covering damage in southwestern Montana. However, they did not consider possible land value appreciation due to wildlife nor did they attempt to convert esthetic values into dollars.

\section{Literature Cited}

Aderhold, M. 1985. Game damage. Montana Outdoors 16:31-35.

Adkins, R.J. 1991. An analysis of game damage and game damage complaints in Montana. M. S. Thesis, Montana State University, Bozeman, Mont..

Adkins, R. J. and L. R. Irby. 1994. Private land hunting reststrictions and game damage complaints in Montana. Wildl. Soc. Bull. 22:520-523.

Batzli, G. O. and F. A. Pitelka. 1970. Influence of meadow mouse populations on California grassland. Ecol. 51:1027-1039.

Clay, K., S. Marks, and G. P. Cheplick. 1993. Effects of insect herbivory and fungal endophyte infection on competitive interactions among grasses. Ecol. 74:1767-1777. 
Coughenour, M. B. 1991. Biomass and nitrogen responses to grazing of upland steppe on Yellowstone's (USA) northern winter range. J. Appl. Ecol. 28:71-82.

Dillman, D.A. 1978. Mail and telephone surveys: the total design method. John Wiley and Sons, N.Y.

Frank, D. A. and S. J. McNaughton. 1992. The ecology of plants, large mammalian herbivores, and drought in Yellowstone National Park. Ecol. 73:2043-2058.

Goodwin, B.K. and V. H. Smith. 1995. The economics of crop insurance and disaster aid. AEI Press, Washington, D.C.

Grover, K.E. 1985. Field evaluation of white-tailed deer depredation techniques in southeastern Montana. Montana Dep. Fish, Wildl. and Parks, Helena, Mont.

Johnson, K. N., R. L. Johnson, D. K. Edwards, and C. A. Wheaton. 1993. Public participation in wildlife management: opinions from public meetings and random surveys. Wildl. Soc. Bull. 21:218-225.

Kitchen, D. W. and B. W. O'Gara. Pronghorn, p. 960-971. In: J. A. Chapman and G. A. Feldhamer (eds.), Wild mammals of North America: biology, management, and economics. Johns Hopkins University Press, Baltimore, Md.

Lacey, J. R., K. Jamtgaard, L. Riggle, and T. Hayes. 1993. Impacts of big game on private land in southwestern Montana: landowner perceptions. J. Range Manage. 46:31-37.

Lenzini, P.A. 1992. The evolution of wildlife law in the United States, p. 40-49. In: T. Palmer and R. Aasheim (eds.), Governor's Symp. on North America's Hunting Heritage. Bozeman, Mont.

Leopold, A. 1933. Game management. Charles Scribner's Sons, N.Y.

Mackie, R. J. 1981. Interspecific relationships, p. 487-507. In: O. C. Wallmo (ed.), Mule and black-tailed deer of North America. University of Nebraska Press, Omaha, Nebr.

Matschke, G.H., D.S. deCalesta, and J.D. Harder. 1984. Crop damage and control, p. 647-654. In: L. K. Halls (ed.), White-tailed deer, ecology and management. Stackpole Books, Harrisburg, Penn.

MASS. 1993. Montana Agricultural Statistics. Vol 30. Montana Agricultural Statistics Service, Helena, Mont.

MicNaughton, S. J. 1983. Compensatory plant growth as a response to herbivory. Oikos 40:329-336.

Mussehl, T., J. Gaffney, and D. G. Conklin. 1986. Design for tomorrow: 1985-1990. Montana Dep. Fish, Wildl., and Parks, Helena, Mont.

Nelson, J. R. 1982. Relationships of elk and other large herbivores, $p$. 415-441. In: J. W. Thomas and D. E. Toweill (eds.), Elk of North America: ecology and management. Stackpole Books, Harrisburg, Penn.

Nelson, J. R. and T. A. Leege. 1982. Nutritional requirements and food habits, p. 323-367. In: J. W. Thomas and D. E. Toweill (eds.), Elk of North America: ecology and management. Stackpole Books, Harrisburg, Penn.

Palmer, W.L., G.M. Kelly, and J.L. George. 1982. Alfalfa losses to white-tailed deer. Wildl. Soc. Bull. 10:259-261.

Peek, J. M. 1984. Northem Rocky Mountains, p. 497-504. In: L. K. Halls (ed.), White-tailed deer, ecology and management. Stackpole Books, Harrisburg, Penn.

Peek, J. M. and P. D. Dalke. (eds.) 1982. Wildlife-livestock relationships symposium; proceedings 10 . University of Idaho, For. Wildl., and Range Exp. Sta, Moscow, Ida.

Quinn, M. A., P. S. Johnson, C. H. Butterfield, and D. D. Walgenbach. 1993. Effects of grasshopper (Orthoptera:Acrididae) density and plant composition on growth and destruction of grasses. Environ. Ento. 22:993-1002.

Rimby, N.R., R. L. Gardner, and P.E. Patterson. 1991. Wildlife depredation policy development. Rangelands 13:272-275.

Saltiel, J. and L. Faulkner. 1991. 1991 Montana farm and ranch survey summary. Montana Agr. Exp. Sta. Spec. Rep. 43. Montana State University, Bozeman, Mont.

Saltiel, J. and L. Faulkner. 1992. 1992 Montana farm and ranch survey summary. Montana Agr. Exp. Sta. Spec. Rep. 45. Montana State University, Bozeman, Mont.

Saltiel, J. and L. Faulkner. 1993. 1993 Montana farm and ranch survey summary. Montana Agr. Exp. Sta. Spec. Rep. 49. Montana State University, Bozeman, Mont.

Saltiel, J. and L. Faulkner. 1994. 1994 Montana farm and ranch survey summary. Montana Agric. Exper. Sta. Spec. Rep. 52. Montana State University, Bozeman, Mont.
SAS. 1987. SAS Version 6.04. SAS Institute Inc., Cary, N.C.

Seagle, S. W. and J. S. McNaughton. 1992. Spatial variation in forage nutrient concentrations and the distribution of Serengeti grazing ungulates. Landscape Ecol. 7:229-241.

Selting, J. P. 1994. Seasonal use of agricultural lands by mule deer, white-tailed deer, and pronghorn antelope in Carter County, Montana. M.S. Thesis, Montana State University, Bozeman, Mont. 66pp.

Short, H. L. 1981. Nutrition and metabolism, p. 99-127. In: O. C. Wallmo (ed.), Mule and black-tailed deer of North America. University of Nebraska Press, Omaha Nebr..

Tebaldi, A. 1979. Effects of deer use on winter wheat and alfalfa production. Wyoming Game and Fish, Final Rep. Res. Proj. FW-3-R-26. Cheyenne, Wyo.

USDA Agricultural Marketing Service. 1993. Montana hay prices. USDA, Billings, Mont.

USDA Agricultural Statistics Service. 1993. Agricultural prices - 1992 summary. USDA Washington, D.C.

USDA Geographic Area Services. 1987. U. S. Census of Agriculture, Montana State and County Data. USDA. Washington, D. C.

Verme, L. J. and D. E. Ullrey. 1984. Physiology and nutrition, p. 91-118. In: L. K. Halls (ed.), White-tailed deer, ecology and management. Stackpole Books, Harrisburg, Penn.

Vining, J. And A. Ebreo. 1991. Are you thinking what I think you are? a study of actual and estimated goal priorities and decision preferences of resource managers, environmentalists, and the public. Soc. and Nat. Resources 4:177-196.

Wallace, L. L. and S. A. Macko. 1993. Nutrient acquisition by clipped plants as a measure of competitive success: the effects of compensation. Functional Ecol. 7:326-331.

Wood, A. K., R. J. Mackie, and K. L. Hamlin. 1989. Ecology of sympatric populations of mule deer and white-tailed deer in a prairie environment. Montana Dep. Fish, Wildl., and Parks, Helena, Mont.

Wywialowski, A. P. 1994. Agricultural producers' perceptions of wildlife-caused losses. Wildl. Soc. Bull. 22:370-382. 